\title{
The research of Ningxia Hui Autonomous Region's Halal food Muslim supply chain in Silk Road Economic Belt
}

\author{
Liu Jiangong ${ }^{1}$ \\ ${ }^{1}$ Beifang University of Nationalities, Yinchuan, Ningxia Hui Autonomous Region, China, 750021 \\ aEmail:360702252@qq.com \\ *Corresponding author: Liu Jiangong
}

\begin{abstract}
The Silk Road Economic Belt dues to the rapid development of transportation and communication technology. Halal food Muslim supplies have become the primary task. The common construction of Halal food Muslim supplies supply chain is an important task, and is the core strategy of Ningxia to the West open. In this paper, the author supplies chain process and key links of the chain. From data collection and on-the-spot investigation through Ningxia Hui Muslim food use, review on the development of the Ningxia and improve the situation from the perspective of the Silk Road Economic belt.
\end{abstract}

Keywords: The Silk Road Economic Belt; Halal food Muslim supplies; supply chain; Ningxia

\section{Introduction}

Halal food is the food and Halal standard agreement, referring form the slaughter and processing production to achieve Halal food requirements and in accordance with the teachings of Islam and Muslims requirements of non-staple food eating habits. Muslim activities specified with the Muslim belief activities. Muslim is a special vocabulary Chinese Muslims for hundreds of years of use, not only has the rich traditional culture and Islamic culture China profound connotation after combination, and in accordance with the Chinese Muslim beliefs and psychological, customs and behavior. [1]

\section{The Silk Road Economic Belt in Ningxia Halal food Muslim supplies supply chain status}

The Silk Road Economic Belt is formed on the basis of the concept of the ancient Silk Road through the two continents. The Silk Road Economic Belt relates to country, large population, the relationship between related products supply chain is extremely complex.

According to the characteristics of this region can be divided as to China section starting point at the eastern end of the Silk Road Economic Belt, three layer section of west area is divided into functional differences: one is the Central Economic Zone, including Kazakhstan, Kyrgyzstan, Tajikistan, Uzbekistan, Turkmenistan, Central Asia economic zone is the "core area of the Silk Road Economic Belt". In 2012, Central Asia (excluding China) had a total population of 65000000 people, GDP $\$ 298700000000$. Two is the ring of Central Asian Economic Zone, including Russia, Afghanistan, Pakistan, Iran and other countries; three is the Asia Europe economic belt cover ring, Central Asia, Europe and North Africa. Countries along the silk road is connected with the mountains and rivers, many people believe in Islam, similar to the Ningxia Muslim customs.[2]

Ningxia is located in the northwest of China and North China border, in the middle position of the new Eurasian Continental Bridge domestic segments, northwest and North China is the link between northwest and southwest 
traffic thorough fare. It has completed a comprehensive transportation network in railway, highway, shipping as a whole, forming a central region, East into the Hexi Corridor, Xinjiang, convenient channel and then to Central Asia, Europe and other countries. In the Silk Road Economic Belt, Ningxia has special advantages.

Ningxia Halal food Muslim supplies industry has formed the Halal food Muslim supplies, dairy processing, grain and oil, Halal meat products, Halal food, Halal leisure health products and catering industry, a complete industrial chain. Ningxia Halal food Muslim supplies industry at present annual operating income reached about 20000000000 Yuan, Halal food Muslim supplies for the whole autonomous region food industry $80 \%$. Formed with WuZhong as the core of the Halal food Muslim supplies industry, WuZhong as the core industry, dairy products as the core of Lycium barbarum Zhongning characteristic industry, Wu Zhong -Zhongwei as the core of the Featured Forestry and fruit industry, Kohara Nishiki as the core of the potato and small coarse industry.

In the halal food Muslim supplies processing base, Ningxia built 15 Moslem food Muslim supplies industrial park, processing zones. Ningxia halal food industry throughout the autonomous region, the halal food enterprises in the region of chain operation and brand to the area outside the output. Wu Zhong, Guyuan, sheep and cattle farming, halal beef and mutton processing industry, Shizuishan halal dehydrated vegetables are full of characteristics.

Muslim commodities industry mainly includes Muslim dress religious activities back to the medical medicine Muslim cultural activities etc.. Focus on the formation of Wu Zhong, Ningxia Muslim supplies industrial park. Driven by the core enterprise, development of ethnic garment, design and production of traditional Muslim clothing, daily wear, fashion costume, in religious activities at the clothing, different grades of Muslim clothing and ethnic performance outfit, and sleeveless jacket, hat, scarf, hijab, decorative lace and other rich and colorful costumes, Ningxia has become the distributed national Muslim clothing, apparel production and wholesale to.

In Muslim supplies accessories, daily necessities, souvenirs and other aspects, focusing on development and production of bath soup bottle, decorative carpet, wall hanging blanket with strong ethnic style of the daily necessities. At the same time the introduction of advanced equipment and production technology, production of Tan sheep and colorful fur and Beach sheepskin products and with national characteristics class bedding, clothing, fur clothing and other Muslim supplies. Formed from the design, production, traditional processing trade, e-commerce supply chain network, supply chain has been extended to the United Arab Emirates, Saudi Arabia, Iran, Europe and the United States and parts of the country. [3]

\section{The Silk Road Economic Belt of Halal food Muslim supplies supply chain Analysis.}

In general the Halal food Muslim supplies supply chain is composed of the food and agriculture industry retail enterprises and logistics companies and other related enterprises constitute network. A raw material production and processing sales and logistics of Halal food Muslim supplies supply chain link.

\subsection{Silk Road Economic Belt of Halal food Muslim supplies of raw materials procurement}

The Silk Road Economic Belt in the core region of the country is mainly Muslim countries, Halal food Muslim supplies of raw materials is the primary link to influence the Halal food Muslim supplies doctrine purity, quality and safety, raw materials procurement meets Halal requirements can largely ensure true Muslim Halal Food Muslim supplies. The Silk Road Economic Belt of Halal food Muslim supplies raw materials into plant materials and animal raw materials, regardless of the type of material can meet the strict requirement of the Muslim. 


\subsection{Silk Road Economic Belt of Halal food Muslim supplies Quality management}

Halal food Muslim supplies will not allow adding industrial additives harmful to human body, even feeding animal raw materials must also Halal. If the feed is not Halal so the fed animal meat also belong to different food Halal code. The Silk Road Economic Belt from non Muslim Halal Food Muslim supplies purchase raw material, processed products should prove effective with Halal approved.

\subsection{Silk Road Economic Belt of Halal food Muslim supplies processing.}

Halal food Muslim supplies compliance must be in conformity with the relevant requirements of the Islamic teachings in the production processing link. Muslims around the world are only observed a doctrine of code, is the "Koran". First of all, the Silk Road economic belt production, all countries business Halal food Muslim supplies practitioners shall not Halal custom taboo food, raw materials into the Halal food Muslim supplies production, management place. Secondly, in the food processing field, it should be taken to meet the muslin eating and drinking customs measures, Muslim food Muslim supplies production and processing field and non Halal food Muslim supplies production and processing of field isolation. Third, the Silk Road economic belt machine equipment used in countries of Halal food Muslim supplies processing and production, must be not be dirt pollution Islamic doctrine thought. Finally, no matter which country are not with the Muslim taboo words and patterns printed on the Halal food Muslim supplies packaging, Halal food Muslim supplies packaging will not sell or transfer.

\subsection{Silk Road Economic Belt of Halal food Muslim supplies logistics.}

The Silk Road Economic Belt in the countries have done smooth supply of history, now with the help of the new Eurasian Continental Bridge, Eurasian air corridor, seamless docking in these countries in the Silk Road Economic Belt of Halal food Muslim supplies logistics park. From Ningxia out of Halal food Muslim supplies in addition to ensure strict avoidance and poisonous and harmful, have peculiar smell, easily contaminated items contact, ensure the Halal food Muslim supplies storage security, Halal food Muslim supplies warehouse must be dedicated to the warehouse, and non strict separated Muslim supplies, to unify the Silk Road economy in countries with logistics identification. [4]

\section{In the Silk Road Economic Belt Ningxia Halal food Muslim supplies a complete supply chain system construction barriers}

The silk road is the core zone in the economic belt of the five Central Asian countries development disadvantage is the biggest obstacle in Ningxia Halal food Muslim supplies international trade going out. The five Central Asian countries manufacturing industry is relatively backward, the main reason is the disintegration of the Soviet Union led to economic ties the original interrupt, make the mechanical manufacturing in the industrial production accounts for the proportion to drop substantially. In 2011, Kazakhstan is a net importer of machinery and equipment products, imports accounted for the total consumption of the domestic machinery products $92.1 \%$. In addition, the five Central Asian countries the processing industry is relatively backward, the processing of agricultural products of Kazakhstan as an example, in 2012, processing of agricultural products accounted for $5 \%$ of gross industrial production industry GDP $16 \%$.

\section{In the Silk Road Economic Belt Ningxia Halal food Muslim supplies a complete supply chain system strategy construction.}

\subsection{Speed up the construction of Muslim node cluster supply chain food Muslim supplies.}

Based on the existing Halal food Muslim supplies industrial park construction, to further expand the Ningxia Halal food Muslim supplies the size of the park, and actively introduce well-known international Halal food Muslim supplies 
company, perfect the Halal food Muslim supplies full chain of supply and demand. In the construction of Ningxia Silk Road Economic Belt of Halal food Muslim supplies certification, $\mathrm{R} \& \mathrm{D}$ design, production and processing, display and trade and distribution center, formed in line with the world standard of the Silk Road Economic Belt important Halal food Muslim supplies industrial agglomeration area. Countries in the Middle East and Central Asia, product certification, industrial technology, agricultural products processing and other aspects of in-depth exchanges and cooperation.

\subsection{Promote Halal food Muslim supplies node seamless cooperation}

Ningxia is an important Muslim food Muslim supplies supply chain. With the construction of the inland open economic Experimental Zone, has formulated the Halal food Muslim supplies the national standard, greatly promoted the Halal food Muslim supplies industrial development, to establish and perfect the Halal food Muslim supplies standard and system. The Silk Road Economic Belt of the five Central Asian countries as an Islamic country, from the Kazakhstan food industry development, food production in the whole processing industry output value accounted for $16.5 \%$ of the share of food production structure in the food processing industry, meat processing fruit and vegetable fat milk bread are main components of food processing output value in 2013 for $\$ 5260000000$, production to meet domestic market demand $77 \%$ thus, $23 \%$ need to import from abroad, give full play to the advantages of Ningxia food standard certification, the development of food import and export trade, especially the development of processing in the food of meat and advantages of high value-added products has not yet developed depression, to provide export more broad market and space for such goods.

\subsection{Application of modern logistics technology Unicom Silk Road Economic Belt of Halal food Muslim supplies supply chain}

Because its food has decided to diversify fast consumer requirements, relying on the logistics technology, in the Silk Road Economic Belt of Halal food Muslim supplies raw materials cultivation, transportation of raw materials, to the distribution center, to food processing production until finally reaching the consumer retailer, whole process, comprehensive control, through the use of cold chain GPSRFID technology equipment and technology, changing the traditional mode of logistics, logistics supply chain management mode to change by low cost, efficient way to maximize the value of the whole supply chain industry.

\subsection{The implementation of brand oriented Halal food Muslim supplies supply chain strategy}

To enterprises as the mainstay, increase the company's encouragement and support, promote the enterprises to become more A Well-Known Trademark in China and China brand-name products. Actively implement the standardization strategy, promote the enterprises to adopt national standards and international advanced standard, carry out certification standards, participate in the formulation of national or international standards, through the use of standardized strategy to enhance quality, improve the production efficiency and the international market capacity. Make full use of Arab China Expo, build on the Silk Road Ningxia channel, build a strategic node Arab land Silk Road with "international standard", the construction of China Arab trade investment demonstration area, international Halal food Muslim supplies and Muslim supplies R \& D certification of production and Trade Center, will be built in Ningxia China Arab international cooperation bridgehead.

\subsection{HALAL certified halal food Muslim supplies supply chain in the Silk Road Economic Belt.}

With the resurgence of protectionism in international 
trade and international trade barriers increase, Ningxia halal food Muslim supplies supply chain extends westward facing a severe situation, we must recognize the situation, face the reality, to actively respond to. Actively respond to foreign technical barriers. Suggest the Department concerned and the detection mechanism of comprehensive, accurate, timely collected export market countries or regions of the access standards, and publicity to all Muslim food Muslim supplies export enterprises, how to according to different countries or regions adopt different detection, obtain different certification guidance and services. At the same time, to encourage the local detection mechanism to strengthen and foreign authoritative testing organizations authorized or cooperation, mutual recognition of qualifications of foreign authoritative testing organizations, convenient and promote the enterprise to obtain the relevant certification.

\section{Conclusions and Perspective}

The Silk Road in the economic zone of the Ningxia Hui Autonomous Region Muslim food Muslim supplies supply chain, strengthen Ningxia and northwest provinces and the five Central Asian countries, economic, and cultural exchanges and cooperation in Europe, promote the whole Chinese halal food Muslim supplies supply chain system development to a higher level. Ningxia halal food Muslim supplies supply chain from Central Asia to Europe through, will be the formation of market and management of Ningxia and Central Asia, Europe has never had a complementary relationship. The Ningxia Hui Autonomous Region is also the halal food Muslim supplies out of the necessary premise to, West development. In the implementation process of the construction of the Ningxia Hui Autonomous Region Muslim food Muslim supplies of the supply chain, to pay attention to the construction of the origin of Ningxia Muslim food Muslim supplies supply chain node. At the same time, to promote the construction of the Silk Road in Muslim countries economic belt of halal food Muslim supplies the relevant market. Based on common HALAL compliance certification, through the modern logistics and technology support, realize the informationization of halal food Muslim supplies supply chain system.

\section{References}

[1] Wang Zhengwei: "Introduction of Hui folklore", Ningxia people's Press, 1994.

[2] Point research group of Ningxia Academy of Social Sciences and Yinchuan Municipal Bureau of commerce: "Twelfth-Five-Year Plan and the 2020 Vision of Halal food Muslim supplies industry", 2010.

[3] "To build Ningxia as a strategic fulcrum of the Silk Road Economic belt", Interview with Liu Hui, the Ningxia Hui Autonomous Region President. 2014,15.New business weekly.

[4] Liu Jiangong: "Research on the Traceability System of Halal identification and the Safety Based on the Internet"2013.12.,Journal of Beifang University of Nationalities. 